\title{
KEMAMPUAN KOGNITIF SISWA YANG DIAJAR DENGAN MODEL ROTATING REVIEW DAN TWO STAY TWO STRAY PADA POKOK BAHASAN HIDROLISIS GARAM
}

\section{STUDENT COGNITIVE ABILITY TAUGHT USING ROTATING REVIEW AND TWO STAY TWO STRAY MODELS ON THE SUBJECT OF SALT HIDROLYSIS}

\author{
Ratna Kusumawardani*, Ria Retnowati, Iis Intan Widiyowati \\ ${ }^{I}$ Program Studi Sarjana Pendidikan Kimia, Fakultas Keguruan dan Ilmu Pendidikan, Universitas Mulawarman \\ Samarinda, Kalimantan Timur, Indonesia \\ *Corresponding Author: nana_chemistry@yahoo.com
}

\begin{abstract}
ABSTRAK
Penelitian ini bertujuan untuk mengetahui perbedaan kemampuan kognitif atara siswa diajar dengan model pembelajaran rotating review dan siswa yang diajar dengan model two stay two stray pada materi hidrolisis garam di SMA Negeri 5 Samarinda, Indonesia. Jenis penelitian ini merupakan penelitian kuantitatif jenis quasi-eksperimental dan desain post-test only control group. Subjek dalm penelitian ini dipilih menggunakan teknik purposive sampling. Terdapat satu kelompok siswa (siswa kelas XI IPA 2) yang diajar menggunakan model pembelajaran rotating review dan satu kelompok siswa (siswa kelas XI IPA 3) yang diajar menggunakan model pembelajaran two stay two stray. Nilai kemampuan kognitif siswa diperoleh dari nilai post test dan ulangan harian. Rata-rata nilai kemampuan kognitif siswa dianalisis menggunakan $t$-test. Hasil penelitian menunjukkan rata-rata kemampuan kognitif siswa kelas XI IPA 2 dan siswa kelas XI IPA 3 adalah 75,48 dan 70,84. Hasil uji-t menunjukkan kedua nilai rata-rata tesebut berbeda signifikan $(\alpha=0,05)$. Berdasarkan hasil analisis data diperoleh kesimpulan bahwa kemampuan kognitif siswa yang diajar dengan model pembelajaran rotating review lebih baik daripada kemampuan kognitif siswa yang diajar menggunakan model pembelajaran two stay two stray.
\end{abstract}

Kata kunci: Diskusi, kemampuan kognitif , poster, soal terbuka

\begin{abstract}
This study aimed to determine the differences in cognitive abilities between high school students taught using rotating review model and high school students taught using two stay two stray model on the subject of salt hydrolysis at SMA Negeri 5 Samarinda, Indonesia. This research is quantitaive research, a quasi-experimental method with post-test only control group design. Subject in this research was choosen by using purposive sampling. There was a group of student (student of XI IPA 2) who taught using rotating review model and a group of student (student of XI IPA 3) who taught using two stay two stray model. Cognitive ability of the students was collected from post test and final subject examination. Mean of student cognitive ability was annalized using t-test. The result shows that the mean of student ability of XI IPA 2 students and XI IPA 3 students were 75.48 and 70.84 . The t-test result shows that both of the mean was significantly diffferent $(\alpha 0.05)$. Based on the data analysis, it can be conclude that the student cognitive ability who taught using rotating review is better than that of student who taught using two stay two stray model.
\end{abstract}

keywords: discussion, cognitive skills, posters, open questions 


\section{PENDAHULUAN}

Ilmu kimia adalah cabang ilmu pengetahuan alam (IPA) yang mempelajari kajian tentang struktur, komposisi, sifat dan perubahan materi serta energi yang menyertai perubahan tersebut. Mata pelajaran kimia merupakan produk pengetahuan alam yang berupa fakta, teori, prinsip, dan hukum dari proses kerja ilmiah. Jadi, dalam pelaksanaan pembelajaran kimia harus mencakup tiga aspek utama yaitu produk, proses, dan sikap ilmiah (Wasonowati, dkk, 2014). Salah satu materi yang mencakup ketiga aspek tersebut adalah hidrolisis garam. Materi hidrolisis garam mempelajari tentang konsep hidrolisis, reaksi dan perhitungan kimia yang membutuhkan kemampuan pemahaman yang baik oleh siswa.

Pembelajaran kimia pada materi hidrolisis selama ini menggunakan model pembelajaran langsung. Model pembelajaran ini dinilai kurang menarik bagi siswa, karena kurangnya interaksi antar siswa, sehingga membuat siswa merasa bosan dan terkadang merasa jenuh. Akibatnya banyak siswa yang kurang menguasai materi hidrolisis garam, sehingga hasil belajar yang diperoleh siswa kurang maksimal. Untuk mengatasi hal tersebut, perlu adanya variasi model pembelajaran pada materi hidrolisis garam. Model yang dipilih sebaiknya model yang melibatkan aktivitas siswa dalam belajar, dapat menumbuhkan kemampuan berfikir kritis, dan membuat siswa mampu mengkonstruksi pemahaman sendiri sehingga dapat meningkatkan hasil belajar siswa.

Hasil belajar siswa dinilai dari 3 aspek pengetahuan yaitu aspek kognitif, aspek afektif, dan aspek psikomotorik. Apapun jenis mata pelajarannya selalu menggunakan ketiga aspek tersebut, namun memiliki penekanan yang berbedabeda (Nurbudiyani, 2013). Kemampuan kognitif merupakan kemampuan sebuah konstruksi proses yang melibatkan otak. Ini termasuk kemampuan untuk berfikir, mengingat, memecahkan masalah dan mengambil keputusan. Kemampuan kognitif ini penting untuk diperhatikan.

Salah satu cara untuk meningkatkan kemampuan kognitif adalah dengan menjadikan suasana belajar pembelajaran menjadi lebih menarik, antara lain dengan memberikan stimulasi pada siswa. Disinilah guru memegang peranan penting dalam mengembangkan kemampuan kognitif siswa. Suasana belajar yang menarik dapat didukung dengan penggunaan model pembelajaran yang menarik. Model pembelajaran yang dapat menarik minat siswa dan mendukung dalam meningkatkan kemampuan kognitif siswa adalah model pembelajaran kooperatif.

Beberapa tipe model pembelajaran kooperatif yang mendukung pemahaman dan keterampilan siswa dalam pemecahan soal atau permasalahan sebagai suatu stimulus, antara lain rotating review dan two stay two stray. Kedua tipe model pembelajaran kooperatif ini berbasis soal dan permasalahan yang dipecahkan melalui diskusi dengan tim kelompoknya. Persamaan lain adalah bahwa kedua tipe model kooperatif ini adalah keduanya sama-sama menekankan pada review atau telaah soal-soal dengan melihat dan mempertimbangkan berbagai jawaban soal yang berasal dari kelompok-kelompok lain. Model pembelajaran ini selain dinilai mampu mendukung pemahaman siswa juga dinilai menarik karena terdapat diskusi kelompok dan melibatkan pergerakan siswa dalam berpindah tempat dan berpindah kelompok.

Menurut Spencer Kagan aktivitas pembelajaran rotating review dapat mendorong siswa untuk siap berfikir kritis dan menganalisis dalam kelompok-kelompok belajar (Warsono \& Hariyanto, 2012). Adapun tahap-tahap pelaksanaannya adalah (1) Siswa dibagi kelompok kecil, (2) Guru memasang gambar atau tulisan berupa poster di beberapa titik, (3) Setiap kelompok berpindah dari poster satu ke poster yang lain untuk mengerjakan soal atau permasalahan yang terdapat pada poster secara diskusi kelompok (4) Laporan diskusi kelompok. Penerapan model pembelajaran rotating review dapat meningkatkan aktivitas guru, aktivitas siswa, pemahaman konsep serta ketuntasan pemahaman konsep siswa (Ayuningtyas, dkk, 2019), dapat meningkatkan hasil belajar siswa (Syairul, 2018), dapat meningkatkan berpikir aktif, kritis dan analitis (Nurul, 2017).

Model two stay two stray adalah salah satu model pembelajaran kooperatif yang dapat meningkatkan aktivitas siswa dan menciptakan suasana belajar yang menyenangkan (Indriyani, 2011). Model pembelajaran ini memberikan kesempatan kepada anggota kelompok untuk membagikan hasil atau informasi ke anggota kelompok lain. Tahap-tahap pelaksanaannya adalah (1) Diskusi kelompok, (2) Dua siswa bertamu ke kelompok lain dan dua siswa lainnya tetap di 
kelompoknya untuk menerima tamu (dua orang dari kelompok lain) (3) Siswa kembali ke kelompok asal, (4) Melakukan diskusi kelompok, (5) laporan hasil diskusi kelompok (Lie, 2008). Dengan model pembelajaran ini siswa saling bertukar informasi, siswa memiliki peran dan tanggung jawab untuk mempelajari bahan diskusi bersama kelompok ketika menjadi 'tamu' maupun 'tuan rumah'. Dengan demikian, pengetahuan dan wawasan siswa berkembang, siswa lebih menguasai topik diskusi sehingga hasil belajar siswa dapat ditingkatkan. Penerapan model pembelajaran two stay two stray dapat meningkatkan kemampuan komunikasi matematis siswa (Yunus, 2013), meningkatkan hasil belajar siswa (Ismawati, 2011; Fitrriyah, dkk., 2012), dan meningkatkan aktivitas siswa (Fitriyah, dkk., 2012). Hasil belajar siswa yang menggunakan model pembelajaran two stay two stray berbantuan LKPD lebih baik daripada hasil belajar siswa yang menggunakan model pembelajaran ekspositori (Asmawati, dkk, 2014; Saraswati, 2012).

Berdasarkan uraian tersebut, maka penelitian ini bertujuan untuk mengetahui perbedaan kemampuan kognitif siswa menggunakan model pembelajaran kooperatif tipe rotating review dan two stay two stray pada pokok bahasan hidrolisis garam.

\section{METODE PENELITIAN}

Penelitian dilaksanakan di SMAN 5 Samarinda. Sampel dipilih dengan teknik purposive sampling. Sampel yang digunakan dalam penelitian ini adalah siswa kelas XI IPA 2 yang diajar dengan menggunakan model pembelajaran rotating review dan siswa kelas XI IPA 3 yang diajar dengan menggunakan model pembelajaran two stay two stray. Pada model pembelajaran kooperatif tipe rotating review, guru menyiapkan sejumlah poster yang berisi pertanyaan, serta disediakan juga kolom untuk menempelkan jawaban, guru membentuk kelompok sebanyak 4 orang salah satunya bertugas sebagai penulis, setiap kelompok siswa menghadap ke arah poster yang berbeda-beda, penanda waktu di setel, siswa membaca pertanyaan yang tertulis dalam poster, mencatat jawabannya, serta menempelkan jawabannya pada poster, bila waktu habis setiap kelompok berputar ke kanan, pada saat satu kelompok sampai pada poster yang baru, mereka tidak hanya harus membaca pertanyaan dan menjawabnya, tetapi juga wajib membaca jawaban kelompok yang semula menghadap poster tersebut.
Jika kelompok yang baru itu tidak paham terhadap jawaban kelompok sebelumnya mereka membubuhkan tanda tanya, tetapi mereka tidak diperbolehkan menyalin jawaban yang diberikan oleh kelompok sebelumnya itu, hal ini berlangsung terus menerus hingga setiap kelompok mengunjungi setiap poster.

Pada model pembelajaran kooperatif tipe two stay two stray, siswa dibagi dalam kelompok terdiri dari 4 orang, guru mengajukan pertanyaan atau suatu topik untuk dibahas dalam bentuk LKS, siswa semula bekerja dalam kelompok terlebih dahulu, setelah selesai, dua orang siswa masing-masing kelompok meninggalkan kelompoknya dan bertamu di kelompok yang lain di dekatnya, dua orang yang tinggal di setiap kelompok bertugas menjelaskan hasil kerja atau membagikan informasi yang diperoleh kelompoknya semula, kepada dua orang tamunya, siswa tamu kembali ke kelompoknya semula dan membagikan informasi yang diperolehnya selama bertamu kepada anggota kelompoknya, anggota kelompok mencocokkan hasil pemikiran kelompok semula dengan hasil bertamu (Warsono \& Hariyanto, 2012). Perbedaan rata-rata nilai kemampuan kognitif siswa diuji menggunakan uji-t pada taraf signifikan 5\%.

\section{HASIL DAN PEMBAHASAN}

Perbedaan nilai rata-rata kemampuan kognitif antara siswa kelas XI IPA 2 dan siswa kelas XI IPA 3 disajikan dalam Gambar 1.

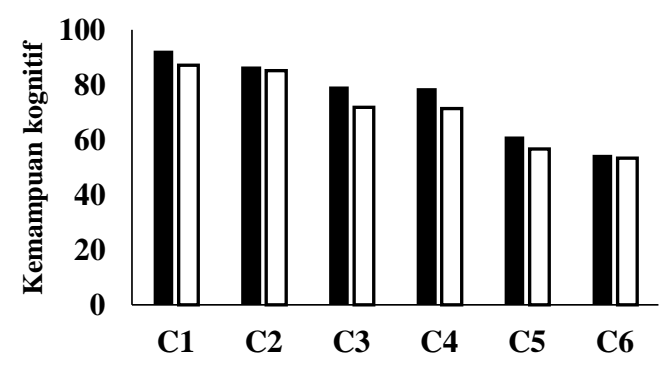

—XI IPA 2 : Model RR 口XI IPA 3 : Model TSTS

Gambar 1. Nilai rata-rata siswa pada setiap aspek kemampuan kognitif

Berdasarkan Gambar 1, terlihat bahwa nilai rata-rata siswa kelas XI IPA 2 yang belajarnya menggunakan model pembelajaran rotating review lebih baik dibandingkan dengan nilai rata-rata siswa kelas XI IPA 3 yang belajarnya menggunakan model pembelajaran two stay two stray. Rata-rata kemampuan kognitif siswa kelas XI IPA 2 dan 
siswa kelas XI IPA 3 adalah 75,48 dan 70,84. analisa uji-t $(\alpha=5 \%)$ menunjukkan bahwa terdapat perbedaan signifikan antara kemampuan kognitif siswa yang belajar menggunakan model pembelajaran rotating review dengan siswa yang belajar menggunakan model pembelajaran two stay two stray.

Lebih baiknya nilai rata-rata kelas XI IPA 2 menunjukkan bahwa tingkat pemahaman siswa pada materi hidrolisis garam lebih baik daripada kelas XI IPA 3, sehingga model pembelajaran rotating review lebih mampu mendukung kemampuan kognitif siswa pada materi hidrolisis garam dibandingkan model pembelajaran two stay two stray.

Beberapa faktor yang menyebabkan kemampuan kognitif siswa dengan menerapkan model pembelajaran rotating review lebih baik dibandingkan dengan kemampuan kognitif siswa dengan menerapkan model pembelajaran two stay two stray yaitu pada model pembelajaran rotating review satu kelompok siswa diberikan soal secara bertahap, jadi masing-masing kelompok siswa hanya mendiskusikan 1 soal secara bersama-sama, hal ini menyebabkan 1 kelompok tersebut lebih fokus dan lebih memahami soal karena seluruh anggota kelompok hanya membahas satu soal yang sama. Sedangkan, dalam model pembelajaran two stay two stray pemberian soal dilakukan secara sekaligus sebanyak 6 soal, hal ini menyebabkan fokus siswa dalam berdiskusi terbagi, siswa cenderung tidak membahas soal bersama-sama, sehingga pemahaman siswa kurang maksimal. Cara menyajikan jumlah soal kepada setiap kelompok untuk didiskusikan berpengaruh terhadap konsentrasi siswa dalam membahas soal atau permasalahan secara bersama-sama.

Pada model pembelajaran rotating review, setiap anggota kelompok secara bersama-sama dapat membaca dan memahami jawaban per nomor soal dari kelompok sebelumnya yang telah mengerjakan. Pada saat ini, jika jawaban kelompok sebelumnya benar dan sesuai dengan pemahaman kelompok mereka, maka siswa secara tidak langsung memperoleh penguatan dalam pemahaman konsep bahwa konsep yang telah mereka pahami telah benar. Hal ini dapat dijadikan sebagai pengulangan konsep pada diri siswa, sehingga semakin banyak tulisan benar yang dibaca siswa, maka semakin meningkatkan pemahaman mereka. Pada saat proses pemberian makna tersebut pembaca tidak begitu saja menerima secara mentah-mentah atau sederhana apa yang dibacanya namun pembaca berusaha untuk menafsirkan makna yang terkandung didalamnya. Aktivitas membaca ini melibatkan banyak hal, tidak hanya sekadar melafalkan tulisan, tetapi juga melibatkan aktivitas visual, berpikir, psikolinguistik, dan metakognitif. Sebagai proses visual, membaca merupakan proses menerjemahkan simbol tulis (huruf) ke dalam kata-kata lisan. Selanjutnya sebagai suatu proses berpikir, proses membaca mencakup aktivitas pengenalan kata, pemahaman literal, interpretasi, membaca kritis, dan pemahaman kreatif. Membaca sebagai proses psikolinguistik, pembaca secara simultan atau terusmenerus menguji dan menerima atau menolak hipotesis yang ia buat sendiri pada saat proses membaca berlangsung. Membaca sebagai proses metakognitif, ialah pembaca mencoba mengaitkan berbagai hal yang dimiliki untuk memahami pesan yang disampaikan penulis terkait materi. Hal ini semakin memudahkan pembaca untuk menuliskan kembali hasil pemahamannya dengan menggunakan bahasanya sendiri. Jadi jika pada saat membaca ini, terdapat tulisan kelompok lain yang belum dipahami, maka siswa dapat membubuhkan tanda tanya untuk perlu dikaji ulang dan siswa tersebut dapat menuliskan jawabannya berdasarkan hasil pemahamannya bersama kelompoknya. Pada model rotating review menggunakan media poster dalam tampilan soal dan masalahnya. Poster ini menggunakan perpaduan warna, garis dan gambar yang disajikan dengan ukuran yang lebih besar dan berbeda dari media yang biasanya digunakan oleh siswa. Hal ini merupakan hal baru bagi siswa belajar dengan menggunakan media poster, yang dapat meningkatkan minat dan motivasi eksternal siswa.

Pada model two stay two stray dimana satu kelompok terdiri dari 4 siswa (kelompok awal) untuk saling diskusi membahas 6 soal. Setelah diskusi dengan kelompok awal, kemudian sebanyak 2 orang siswa bertamu ke kolompok lain, sedangkan 2 orang lainnya menerima tamu dari kelompok lain. Pada kelompok yang baru tersebut siswa saling berdiskusi kembali membahas 6 soal secara langsung. Pada saat diskusi dalam kelompok baru ini, 2 orang siswa yang bertamu ini akan memperoleh atau memberikan pengetahuan yang dipahaminya berdasarkan hasil diskusi sebelumnya. Kedua siswa yang bertamu tersebut akan kembali ke kelompok awal dengan membawa pemahaman yang baru yang lebih lengkap harapannya, untuk dituliskan ke lembar jawaban sebagai hasil diskusi 
kelompok awal. Proses ini satu kelompok hanya mendapatkan informasi hasil diskusi dari 2 kelompok lainnya. Apabila dua siswa yang bertamu atau menerima tamu ini memiliki kemampuan pemahaman yang belum penuh karena keterbatasan kemampuan siswa, maka ketika akan menuliskan hasil diskusi setelah kembali ke kelompok awal akan mengalami sedikit kendala, sehingga akan berdampak pada pemahaman konsep kelompok tersebut. Ini merupakan salah satu kelemahannya. Walaupun pada akhir pembelajaran akan dibahas bersama dengan guru, namun pengalaman belajar yang akan lebih diingat siswa adalah hasil belajar yang berulang ketika diskusi dan dengan menggunakan redaksi yang mudah dipahami karena hasil penjelasan dari teman sebaya.

Namun, kedua model pembelajaran ini dapat melatih siswa lebih aktif dalam pembelajaran, karena siswa diajak untuk berdiskusi, dalam berdiskusi siswa berlatih untuk bertanya dan memberikan pendapatnya berdasarkan pemahaman yang telah terbangun pada dirinya. Keaktifan siswa ini mampu memberikan hasil belajar yang baik. Hal ini sesuai dengan teori yang dikemukakan oleh Rusman (2011) bahwa pembelajaran aktif merupakan suatu bentuk pembelajaran yang lebih banyak melibatkan aktivitas siswa dalam mengakses berbagai informasi dan pengetahuan untuk dibahas dan dikaji dalam proses pembelajaran di kelas, sehingga mereka mendapatkan berbagai pengalaman yang dapat meningkatkan pemahaman dan kompetensinya. Lebih dari itu, pembelajaran aktif memungkinkan siswa mengembangkan kemampuan berfikir tingkat tinggi, seperti menganalisis dan mensintesis, serta melakukan penilaian terhadap berbagai peristiwa belajar dan menerapkan kehidupan sehari-hari. Pada kedua model juga melibatkan aktivitas fisik siswa untuk berpindah dari tempat satu ke tempat yang lain selama proses pembelajarannya, sehingga siswa tidak merasa bosan dan jenuh karena terjadi interaksi antara individu dengan lingkungan sekitarnya. Kedua model ini dapat meningkatkan rasa percaya diri para siswa untuk mengemukakan pendapat dalam diskusi kelompok, mengembangkan kecakapan oral, ketrampilan berbicara, dan kecakapan interaksi sosial dan membangun atmosfer kerjasama serta mengembangkan teknik pemecahan masalah melalui kerja sama rekan sebaya.

Latihan soal yang digunakan pada kedua model ini, merupakan soal terbuka, yang dibuat berdasarkan kemampuan kognitif siswa. Siswa dapat mengemukakan pendapatnya berdasarkan pemahaman yang telah terbangun dalam dirinya melalui proses diskusi dengan teman satu kelompoknya. Pada saat diskusi ini terjadi sharing pendapat jika terdapat perbedaan dalam penafsiran, sehingga dapat memunculkan kemampuan berfikir kritis siswa karena melihat dari sudut pandang yang bisa berbeda. Menurut Silver dengan pemberian soal terbuka siswa mempunyai banyak pengalaman dalam menafsirkan masalah, dan memungkinkan dapat membangkitkan gagasan yang berbeda bila dihubungkan dengan penafsiran yang berbeda (Khabibah, 2006). Selanjutnya Heddens dan Speer mengungkapkan bahwa dengan pemberian soal terbuka, dapat memberi rangsangan kepada siswa untuk meningkatkan cara berpikirnya, siswa memiliki kebebasan untuk mengekspresikan hasil eksplorasi daya nalar dan analisanya secara aktif dan kreatif dalam upaya menyelesaikan suatu permasalahan (Mustikasari, 2010).

\section{SIMPULAN}

Kemampuan kognitif siswa pada materi hidrolisis garam yang diajar menggunakan model pembelejaran rotating review lebih baik dari siswa yang diajar dengan model pembelajaran two stay two stray.

\section{UCAPAN TERIMAKASIH}

Penulis mengucapkan terima kasih kepada SMA Negeri 5 Samarinda yang telah memberikan ijin untuk melakukan penelitian ini.

\section{DAFTAR PUSTAKA}

Asmawati, R. dan Wuryanto, W. 2014. Keefektifan model pembelajaran LC 5E dan two stay two stray berbantuan LKPD terhadap hasil belajar. KREANO: Jurnal Matematika Kreatif Inovatif. 5(1), 26-32.

Ayuningtias, E.I., Sutisnawati, A., dan Amalia, A.R. . 2019. Penerapan model kooperatif tipe rotating review untuk meningkatkan pemahaman konsep IPA pada siswa kelas tinggi. Attadib: Journal of Elementary Education, 3(2), 1-11.

Indriyani, C. 2011. peningkatan kualitas pembelajaran ips dengan model pembelajaran kooperatif teknik two stay-two stray pada siswa kelas IV SD Tambakaji 05 Kecamatan Ngaliyan Kota Semarang. Jurnal Kependidikan Dasar, 1(2), 180-193.

Ismawati, N. dan Hindarto, N. 2011. penerapan model pembelajaran kooperatif dengan 
pendekatan struktural two stay two stray untuk meningkatkan hasil belajar siswa kelas X SMA. Jurnal Pendidikan Fisika Indonesia, 7(1), 38-41.

Khabibah. 2006. Pengembangan Model Pembelajaran Matematika demgan Soal Terbuka untuk Meningkatkan Kreativitas Siswa Sekolah Dasar. Disertasi. Surabaya: Program Pascasarjana Unesa.

Lie, A. 2008. Mempraktikan Cooperatif Learning di Ruang-Ruang Kelas. PT Gramedia Widiasarana Indonesia, Jakarta.

Mustikasari, M., Zulkardi, Z., dan Asiyah, N. 2010. Pengembangan soal soal open-ended pokok bahasan bilangan pecahan di sekolah menengah pertama, Jurnal Pendidikan Matematika, 4(2), 45-60.

Nurbudiyani, I. (2013). Pelaksanaan pengukuran ranah kognitif, afektif, dan psikomotor pada mata pelajaran IPS Kelas III SD Muhammadiyah Palangkaraya. Pedagogik Jurnal Pendidikan. $8(2)$.

Fitriyah, N.I., Purwantoyo, E., dan Chasnah. 2012. Efektivitas kooperatif two stay-two stray terhadap aktivitas dan hasil belajar siswa. Unnes Journal of Biology Education, 1(2), 129-135.

Nurul, A. 2017. Implementasi teknik pembelajaran rotating review dalam meningkatkan berpikir kritis dan analitis pada mata pelajaran aqidah akhlak di MTs NU Nurul Huda Kaliwungu Kudus Tahun Pelajaran 2016/2017. Skripsi. Repository STAIN Kudus

Rusman. 2011. Model-Model Pembelajaran Mengembangkan Profesionalisme Guru. Jakarta: PT. Rajagrafindo Persada.

Saraswati, I.D. 2012. Penerapan model pembelajaran two stay-two stray berbantuan lembar kerja peserta didik (LKPD) dan alat peraga terhadap kemampuan pemahaman konsep dan peningkatan minat peserta didik pada materi kubus dan balok kelas VIII SMP N 5 Pemalang tahun pelajaran 2011/2012. Skripsi. Semarang: Universitas Negeri Semarang.

Syairul, S. Kurniaman, O., Lazim, N. 2018. Penerapan model pembelajaran kooperatif tipe rotating review untuk meningkatkan hasil belajar IPA siswa Kelas V SD Negeri 2 Tanjung Medang. Jurnal Online Mahasiswa, 5(1), 1-12.

Warsono dan Hariyanto. 2012. Pembelajaran Aktif Teori dan Asesmen. Bandung: Remaja Rosda Karya.

Wasonowati, R., Redjeki, T., dan Ariani, S. 2014. Penerapan model problem based learning (PBL) pada pembelajaran hukum - hukum dasar kimia ditinjau dari aktivitas dan hasil belajar siswa kelas X IPA SMA Negeri 2 Surakarta tahun pelajaran 2013/2014. Jurnal Pendidikan Kimia, 3(3), 66-75.

Yunus, M., Suyitno, H., Waluyo, S.B. 2013. Pembelajaran two stay two stray berbasis konstruktivisme berbantuan $\mathrm{CD}$ pembelajaran untuk menumbuhkan kemampuan komunikasi matematis siswa. Unnes Journal of Mathematics Education Research, 2(1), 164-169. 